\title{
Green fodder from energy forest farming
}

\author{
MATTI NÄSI') and VELI POHJONEN ${ }^{2}$ )
}

1) Department of Animal Husbandry, University of Helsinki, SF-00710 Helsinki 71

2) The Finnish Forest Research Institute, SF-69100 Kannus

\begin{abstract}
The study examined the yield, chemical composition and nutritive value of energy tree leaves under one year rotation, and considered the methods and results in the entire tree utilization. The proportion of leaves was $31 \%$ for Salix cv. Aquatica and $16 \%$ for S. viminalis of the total biomass yield. The dry matter yield of leaves amounted to 3-5 tn DM/ha. The average chemical composition of willow leaves was as follows: dry matter $27 \%$, ash $7.7 \%$, crude protein $19.5 \%$, ether extract $4.9 \%$, and crude fibre $14.1 \%$. The content of tannins was $4.1 \%$ in willow leaves and $3.4 \%$ in alder leaves. Fertilization had a significant effect on the ash and protein contents of willow leaves. Crude fibre content of alder leaves was higher compared to willow leaves. In vitro digestibility of willow leaves was $64 \%$ for organic matter and pepsine-HCI soluble protein was $65 \%$ on average. Fertilization improved the digestibility $6-8 \%$-units. Calcium content of willow leaves was $10 \mathrm{~g} / \mathrm{kg}$ DM, phosphorus $3 \mathrm{~g} / \mathrm{kg} \mathrm{DM}$ and magnesium $2.8 \mathrm{~g} / \mathrm{kg} \mathrm{DM}$. The amount of trace elements was considerably high. On account of the high content of protein and minerals willow leaves are a considerable source of feed for domestic animals or wild ruminants. The harvesting and conservation of leaves is still a technical question that has to be resolved.
\end{abstract}

\section{Introduction}

Energy forest farming is a discipline of cultivated trees and husban dry in which the solar radiation is collected and converted into biotic energy of the phytomass in the growing trees. The aim is to produce high annual energy yields by selecting, breeding and raising fast-growing deciduous tree crops.

The energy tree crop may be, in Finnish conditions, willow, poplar, alder, aspen and birch. The essential common feature for them is the coppicing ability and fast growth after the harvest.

Promising results in northern energy forest farming have been achieved with the use of selected willow clones (POHJONEN et al. 1980). The first willow experiments were established in 1973. A Danish willow clone, Salix cv. "Aquatica" produced in the latitude of the arctic circle a dry matter yield of about 10 tons/ha already during the first summer (POHJONEN 1974). More willow species have been screened in subsequent experiments. The annual yields have been maintained at their high level, between 10 and 20 tons/ha, in gross energy equivalents between about 160 and 320 gigajoules per hectare. The largest dry matter yield so far 
reported in the Nordic countries has been 32 tons/ha (SIREN and SIVERTSSON 1976), which includes the harvested stemwood only.

The fastest growing clones do not drop their leaves before the autumn frosts and the stems can thus be harvested with green leaves.

With suitable methods in the autumn harvest the leaves could be separated from the stem yield and could be used for instance as a green fodder for animals. In earlier times it was common to utilize forest tree leaves as forage for sheep and cattle. The concept could be developed by using high-yielding varieties and modern animal husbanrdy methods.

The purpose of this study is to find out the amount, chemical composition and nutritive value of energy tree crop leaves, and to consider the methods and results in the whole tree utilization.

\section{Materials and methods}

The study consisted of 36 samples of tree leaves from nine clones of willow (Salix sp.), two samples from the clones of poplar (Populus sp.) and four samples from alder (Alnus incana). The samples were collected on October 10-12, 1979 in the experimental areas of Kannus, Suonenjoki and Suomusjärvi of the Finnish Forest Research Institute. The fertilization in Kannus was per ha N $150 \mathrm{~kg}, \mathrm{P} 60 \mathrm{~kg}$ and $\mathrm{K}$ $255 \mathrm{~kg}$. In Suonenjoki the experimental plots were fertilized with N $250 \mathrm{~kg}$ and from woodash with P $20 \mathrm{~kg}$ anf K $76 \mathrm{~kg}$. In Suomusjärvi there were five different fertilization treatments, 1) without fertilization; 2) woodash 10 tn dry matter, supplied per ha, P $92 \mathrm{~kg}$ and $\mathrm{K} 382 \mathrm{~kg}$; 3) P + Mo, Superphosphate, P $92.4 \mathrm{~kg}$ and $\mathrm{Na}_{2} \mathrm{MoO}_{4} \times 2 \mathrm{H}_{2} \mathrm{O} 6.9 \mathrm{~kg}$; 4) NPK I, N $150 \mathrm{~kg}, \mathrm{P} 92.4 \mathrm{~kg}$ and $\mathrm{K} 382 \mathrm{~kg}$, 5) NPK II, N $150 \mathrm{~kg}$ from urea, P $92.4 \mathrm{~kg}$ and $\mathrm{K} 382 \mathrm{~kg}$.

Dry matter contents were determined by oven heating at $103^{\circ} \mathrm{C}$ and samples for feed analyses were dried in a vacuum oven at $50^{\circ} \mathrm{C}$. The feed analyses were made on the dried samples by standard methods (PALOHEIMO 1969). In vitro digestbility determinations were made by the method of TILLEY and TERRY (1963). Mineral composition of the leaves was determined by atomic absorption spectrophotometer (Varian Techtron AA 1000) and phosphorus by the method of TAYSSKY and SHORR (1953). Tannin determinations were made by Official methods of analysis (1970).

\section{Results and discussion}

The accurate percentages for leaves were determined in Kannus during the autumn harvest, October 23-25. The proportion of leaves of the total, above ground biomass, was $31 \%$ for S.cv. Aquatica and $16 \%$ for S. viminalis as calculated on a dry matter basis.

In Suonenjoki the yield determinations were made per square meter basis due to the small area of the experimental plots. They included figures (stems only) from 1.4 to $3 \mathrm{~kg} / \mathrm{m}^{2}$ for Salix Pa $75,2.6 \mathrm{~kg} / m_{2}$ for $S$. dasyclados and $1.5 \mathrm{~kg} / \mathrm{m}^{2}$ for $S$. phylicifolia. 
A separate measurement for the percentage of leaves was made in Suonenjoki for Salix PA 77. It resembles Salix viminalis and is $19.4 \%$.

More detailed determinations on the accumulation of the biomass, both stems and leaves, were made with Salix cv. Aquatica in Kannus. The leaves consisted of about one third of the total yield of dry matter $(4000 \mathrm{~kg} / \mathrm{ha} v \mathrm{vs} 12000 \mathrm{~kg} / \mathrm{ha})$.

The chemical composition of willow and poplar leaves are presented in Tables 1 and 2. The average dry matter content of leaves was $27 \%$. The ash content in DM was on average $7.7 \%$, and there was relatively wide variation in the ash content of different clones. The crude protein content varied between 12 and $25 \%$ in DM averaging $19.5 \%$. The proportion of true protein from crude protein was on average $4.9 \%$ in DM. Probably this also includes other substances than fat e.q. waxes, resin and green colour. Crude fibre varied between 12 and $19 \%$ and the average was $14.1 \%$. This value is quite low compared to grass species also in an early cut. The protein content of the leaves is considerably higher and the crude fibre content only less than half compared to that of hay.

Table 1. Chemical composition and in vitro-digestibility of different clones of willow and poplar ( $\%$ in dry matter).

\begin{tabular}{|c|c|c|c|c|c|c|c|c|c|c|c|}
\hline Clone & & $\begin{array}{c}\text { Dry } \\
\text { matter }\end{array}$ & Ash & $\begin{array}{l}\text { Crude } \\
\text { protein }\end{array}$ & $\begin{array}{c}\text { True } \\
\text { protein }\end{array}$ & $\begin{array}{l}\text { Ether } \\
\text { extract }\end{array}$ & $\begin{array}{l}\text { Crude } \\
\text { fibre }\end{array}$ & Sugars & NFE & $\begin{array}{l}\text { In vitro dig. } \\
\text { org. matter. }\end{array}$ & $\begin{array}{c}\text { Pepsine } \mathrm{HCl} \\
\text { soluble } \\
\text { protein } \%\end{array}$ \\
\hline Salix cv. Aquatica & 1) & 26.8 & 8.6 & 20.5 & 16.5 & 4.5 & 16.4 & 8.5 & 49.9 & 58.6 & 58.3 \\
\hline S. viminalis & 1) & 30.7 & 7.7 & 18.0 & 14.2 & 4.1 & 15.6 & 7.0 & 54.7 & 75.2 & 51.3 \\
\hline S. triandra & 1) & 23.9 & 8.0 & 12.4 & 8.9 & 3.2 & 19.3 & 7.6 & 57.1 & 52.7 & 37.6 \\
\hline S. cv. Aquatica & 2) & 24.9 & 7.5 & 23.1 & 20.7 & 5.5 & 13.4 & 10.4 & 50.6 & 67.4 & 71.8 \\
\hline S. viminalis & 2) & 27.3 & 8.4 & 23.1 & 19.7 & 5.3 & 13.8 & 8.1 & 49.4 & 63.4 & 70.5 \\
\hline S. smitbiana & 2) & 27.6 & 8.2 & 22.7 & 20.9 & 4.9 & 17.3 & 8.1 & 47.0 & 62.4 & 71.6 \\
\hline S. scbwerinii & 2) & 30.1 & 6.4 & 20.0 & 17.1 & 4.8 & 14.1 & 11.0 & 54.8 & 62.4 & 66.3 \\
\hline S. dasyclados & 2) & 28.3 & 7.7 & 20.7 & 18.2 & 5.5 & 13.6 & 11.1 & 52.6 & 68.0 & 69.0 \\
\hline S. superlauriana & 2) & 25.7 & 7.5 & 21.5 & 19.7 & 5.4 & 13.7 & 10.8 & 51.9 & 52.4 & 61.6 \\
\hline S. fragilis & 2) & 25.0 & 9.9 & 21.6 & 18.8 & 6.5 & 12.9 & 10.1 & 49.2 & 70.6 & 74.8 \\
\hline S. pbylicifolia & 2) & 25.2 & 7.7 & 20.7 & 16.7 & 5.7 & 13.8 & 5.9 & 52.1 & 50.3 & 59.9 \\
\hline Populus laurifolia & 1) & 34.4 & 9.9 & 21.0 & 16.3 & 4.9 & 14.0 & 15.1 & 50.2 & 75.4 & 76.6 \\
\hline P. rasymowskyana & 1) & 28.4 & 9.8 & 20.2 & 15.4 & 4.8 & 14.1 & 13.4 & 51.1 & 73.0 & 74.6 \\
\hline$\tilde{\mathbf{x}}$ & & 27.6 & 8.3 & 20.4 & 17.2 & 5.0 & 14.8 & 9.8 & 51.6 & 64.0 & 64.9 \\
\hline s.d. & & 2.9 & 1.1 & 2.8 & 3.2 & 0.8 & 1.9 & 2.6 & 2.7 & 8.6 & 11.1 \\
\hline
\end{tabular}

1) Samples fram Experiment Station in Kannus

2) Samples fram Experiment Station in Suonenjoki

Table 2. The effect of fertilization on the composition and in vitro-digestibilitv of leaves of Salix cv. Aquatica.

\begin{tabular}{|c|c|c|c|c|c|c|c|c|c|c|c|c|}
\hline $\begin{array}{l}\text { Fertili- } \\
\text { zation }\end{array}$ & $\mathrm{n}$ & $\begin{array}{c}\text { Dry } \\
\text { matter }\end{array}$ & Ash & $\begin{array}{l}\text { Crude } \\
\text { protein }\end{array}$ & $\begin{array}{c}\text { True } \\
\text { protein }\end{array}$ & $\begin{array}{l}\text { Ether } \\
\text { extract }\end{array}$ & $\begin{array}{l}\text { Crude } \\
\text { fibre }\end{array}$ & Sugars & NFE & Tannins & $\begin{array}{l}\text { In vitro } \\
\text { dig. } \\
\text { org. matter }\end{array}$ & $\begin{array}{c}\text { Pepsine } \mathrm{HCl} \\
\text { soluble } \\
\text { protein } \%\end{array}$ \\
\hline Control & 3 & 27.8 & 5.6 & 16.2 & 14.3 & 4.4 & 13.7 & 17.5 & 60.1 & 5.4 & 59.0 & 57.4 \\
\hline Ash & 3 & 27.5 & 6.7 & 17.2 & 14.8 & 4.8 & 14.0 & 19.1 & 57.3 & 4.4 & 64.9 & 61.8 \\
\hline $\mathrm{P}+\mathrm{Mo}$ & 3 & 26.9 & 6.6 & 17.5 & 15.2 & 4.6 & 13.8 & 18.7 & 57.5 & 4.4 & 64.8 & 62.2 \\
\hline NPK I & 3 & 26.4 & 7.5 & 18.9 & 16.3 & 4.7 & 14.0 & 18.1 & 55.0 & 3.6 & 66.9 & 63.3 \\
\hline NPK II & 3 & 26.4 & 7.6 & 18.3 & 16.3 & 4.5 & 13.2 & 18.0 & 56.4 & 3.7 & 66.0 & 63.3 \\
\hline$\tilde{\mathbf{x}}$ & 15 & 26.9 & 6.8 & 17.6 & 15.4 & 4.6 & 13.7 & 18.3 & 57.2 & 4.1 & 64.3 & 61.6 \\
\hline s.d. & & 1.4 & 0.8 & 1.4 & 1.1 & 0.3 & 0.5 & 1.4 & 2.0 & 0.7 & 4.0 & 4.1 \\
\hline
\end{tabular}


content of the leaves is considerably higher and the crude fibre content only less than half compared to that of hay.

Samples of poplar clones had a slightly higher protein content than the willow leaves, but the overall composition was quite similar. The crude fibre content of alder leaves was higher compared to that of the willow leaves.

The review of BECKER and NEHRING (1965) has dealt in detail with the composition of leaves of different natural forest species. The composition of cultivated willow leaves differs in many cases. The willows and poplar had been fertilized and this incresed e.g. the protein content. The protein content of the natural leaves earlier in summer can be quite high, over $20 \%$ in DM, which is the case with nitrogen fixing trees.

Fertilization had a significant effect on the chemical composition of willow leaves (Table 2). The ash content increased with wood ash or phosphorus fertilizer over one percentage unit and with NPK-fertilizer over two percentage units. There was no effect on the ether extract or crude fibre content of willow leaves. The fertilizer markedly reduced the crude fibre content of alder leaves.

In vitro digestibility coefficients are presented in Tables 1, 2 and 3 and also the percentages of pepsine $\mathrm{HCl}$ soluble protein of crude protein, which indicate the value of leaves as a feed for animals. There was relatively wide variation in the digestibvility among samples from different clones. The average digestibility was 64 $\%$ for organic matter. These correspond with values of good quality hay, but as regards a suitable chemical composition it would be 70-80\%. Pepsine $\mathrm{HCl}$ soluble protein was on an average $65 \%$ and this is also low for such a high protein content. Poplar leaves were higher in digestibility and pepsine $\mathrm{HCl}$ soluble protein. Some clones of willow S. viminalis and S. fragilis had in vitro digestibility over $70 \%$. The alder leaves were poorly digested in vitro, $45 \%$, and the pepsine $\mathrm{HCl}$ soluble protein was only $40 \%$. The values were $20-25 \%$ units lower than in willow leaves. Fertilization improved the digestibility $6-8 \%$ units and the pepsine $\mathrm{HCl}$ soluble protein 4-6\% units.

The tree leaves contain tannins which reduce the digestibility and protein utilization. The content of tannins in willow leaves was on average $4.1 \%$. In alder leaves the value was $3.4 \%$. BECKER and NEHRING (1965) present $2.8 \%$ for alder. The content of tannins in willow leaves was negatively correlated to the pepsine$\mathrm{HCl}$ soluble protein $(-0.67 \mathrm{xx})$ and to organic matter in vitro digestibility ($\left.0.68^{x x}\right)$. The tannin content in leaves increases during the growth period, and the

Table 3. Chemical composition and in vitro-digestibility of alder leaves, Alnus incana.

\begin{tabular}{lcccccccccccc}
\hline $\begin{array}{l}\text { Fertili- } \\
\text { zation }\end{array}$ & $\begin{array}{c}\text { Dry } \\
\text { matter }\end{array}$ & & Ash & $\begin{array}{c}\text { Crude } \\
\text { protein }\end{array}$ & $\begin{array}{c}\text { True } \\
\text { protein }\end{array}$ & $\begin{array}{c}\text { Ether } \\
\text { extract }\end{array}$ & $\begin{array}{c}\text { Crude } \\
\text { fibre }\end{array}$ & Sugars & NFE & Tannis & $\begin{array}{c}\text { In vitro dig. } \\
\text { org. matter. }\end{array}$ & $\begin{array}{c}\text { Pepsine HCl } \\
\text { soloble } \\
\text { protein, } \%\end{array}$ \\
\hline Control & 32.8 & 5.4 & 17.6 & 16.2 & 3.7 & 23.7 & 11.4 & 49.7 & 3.2 & 36.7 & 30.9 \\
Ash & 29.9 & 5.7 & 17.8 & 16.3 & 5.2 & 17.7 & 15.1 & 53.6 & 4.1 & 42.7 & 43.9 \\
NPK I & 30.2 & 7.3 & 17.6 & 16.6 & 3.8 & 19.9 & 13.1 & 51.4 & 2.6 & 44.7 & 35.3 \\
NPK II & 29.0 & 6.5 & 17.8 & 16.3 & 4.7 & 17.3 & 15.8 & 53.8 & 3.8 & 46.7 & 48.0 \\
\hline & $\dot{x}$ & 30.5 & 6.2 & 17.7 & 16.4 & 4.3 & 19.6 & 13.8 & 52.1 & 3.4 & 42.7 & 39.5 \\
& s.d. & 1.6 & 0.9 & 0.1 & 0.2 & 0.8 & 2.9 & 2.0 & 1.9 & 0.7 & 4.4 & 7.8 \\
\hline
\end{tabular}


values in the autumn are twice as high as in the spring (BECKER and NEHRING 1965).

The digestibility of different species varies widely, while also the age of the leaves has a considerable influence (BECKER and NEHRING 1965). The digestibility of Canadian poplar (Populus canadiensis) can be as high as $86 \%$ in the early growth stage while it decreases to $50 \%$ in autumn. In vivo-digestibilities of pressed pulp of willow leaves with leaf protein production measured with rams were $60 \%, 61 \%$ and $52 \%$ for dry matter, organic matter and crude protein, respectively (NÄSI to be published). In vitro-digestibilities were in good accordance with in vivoresults. The digestibility of willow leaves for growing pigs was $41 \%$ for organic matter (NÄSI to be published).

The mineral composition of willow and poplar leaves is presented in Table 4, the effect of fertilization on the mineral composition of willow leaves, $S . c v$. Aquatica in Table 5, and the values of alder leaves $A$. incana in Table 6. The calcium content of willow leaves is high, $10 \mathrm{~g}$ per $\mathrm{kg} \mathrm{DM}$, which exceeds the value of grass species. The phosphorus content is $3 \mathrm{~g}$ per $\mathrm{kg} \mathrm{DM}$, which corresponds to the value of grass species. Magnesium content was on an average $2.8 \mathrm{~g}$ per $\mathrm{kg} \mathrm{DM}$.

Table 4. Mineral composition of leaves of different willow and poplar leaves.

\begin{tabular}{|c|c|c|c|c|c|c|c|c|c|}
\hline Clone & $\mathrm{P}$ & $\underset{\mathrm{g} / \mathrm{kgDM}}{\mathrm{Ca}}$ & $\mathrm{Mg}$ & $\mathrm{K}$ & $\mathrm{Na}$ & $\mathrm{Fe}$ & $\underset{\mathrm{mg} / \mathrm{kg} \mathrm{DM}}{\mathrm{Cu}}$ & $\mathrm{Zn}$ & $\mathrm{Mn}$ \\
\hline Salix cv. Aquatica & 3.60 & 10.47 & 2.27 & 22.29 & 78 & 98 & 8 & 418 & 425 \\
\hline S. viminalis & 4.07 & 8.18 & 4.60 & 19.60 & 192 & 93 & 8 & 165 & 393 \\
\hline S. triandra & 1.67 & 10.37 & 5.37 & 11.16 & 157 & 156 & 9 & 685 & 537 \\
\hline S. cv. Aquatica & 3.25 & 8.13 & 3.13 & 29.59 & 134 & 48 & 8 & 252 & 249 \\
\hline S. viminalis & 4.26 & 10.06 & 3.25 & 26.83 & 166 & 59 & 9 & 304 & 189 \\
\hline S. smitbiana & 3.85 & 12.43 & 3.13 & 25.50 & 128 & 59 & 9 & 202 & 201 \\
\hline S. scbwerinii & 4.38 & 11.52 & 2.93 & 14.00 & 110 & 57 & 4 & 269 & 337 \\
\hline S. dasyclados & 2.52 & 9.21 & 3.36 & 26.69 & 187 & 46 & 4 & 204 & 118 \\
\hline S. superlauriana & 2.84 & 9.21 & 1.84 & 27.76 & 55 & 47 & 3 & 217 & 208 \\
\hline S. fragilis & 4.26 & 11.43 & 2.98 & 33.38 & 61 & 62 & 11 & 429 & 174 \\
\hline S. pbylicifolia & 2.48 & 7.68 & 1.26 & 32.26 & 54 & 69 & 8 & 529 & 205 \\
\hline Populus laurifolia & 4.13 & 7.55 & 2.45 & 31.79 & 99 & 109 & 10 & 124 & 252 \\
\hline P. rasymowskyana & 4.06 & 8.78 & 3.21 & 28.24 & 102 & 116 & 16 & 183 & 188 \\
\hline$\tilde{\mathbf{x}}$ & 3.49 & 9.62 & 3.06 & 25.31 & 117 & 78 & 8 & 306 & 267 \\
\hline s.d. & 0.86 & 1.57 & 1.07 & 6.85 & 48 & 34 & 3 & 164 & 120 \\
\hline
\end{tabular}

Table 5. Effect of fertilization on the mineral composition of willow leaves Salix cv. Aquatica.

\begin{tabular}{|c|c|c|c|c|c|c|c|c|c|c|}
\hline $\begin{array}{l}\text { Fertili- } \\
\text { zation }\end{array}$ & $\mathrm{n}$ & $\mathbf{P}$ & $\begin{array}{c}\mathrm{Ca} \\
\mathrm{g} / \mathrm{kg} \text { DM }\end{array}$ & $\mathrm{Mg}$ & $\mathrm{K}$. & $\mathrm{Na}$ & $\begin{array}{c}\mathrm{Fe} \\
\mathrm{mg} / \mathrm{kg}\end{array}$ & $\begin{array}{c}\mathrm{Cu} \\
\mathrm{DM}\end{array}$ & $\mathrm{Zn}$ & $\mathrm{Mn}$ \\
\hline Control & 3 & 1.54 & 10.31 & 2.99 & 12.12 & 103 & 78 & 12 & 497 & 410 \\
\hline Ash & 3 & 2.04 & 10.89 & 2.19 & 19.08 & 132 & 84 & 10 & 448 & 365 \\
\hline $\mathrm{P}+\mathrm{Mo}$ & 3 & 2.54 & 11.29 & 3.52 & 14.24 & 135 & 83 & 8 & 336 & 451 \\
\hline NPK I & 3 & 2.38 & 8.94 & 1.57 & 26.35 & 134 & 83 & 9 & 289 & 467 \\
\hline NPK II & 3 & 2.43 & 8.84 & 1.51 & 28.57 & 136 & 87 & 11 & 342 & 479 \\
\hline$\hat{\mathbf{x}}$ & 15 & 2.19 & 10.06 & 2.36 & 20.07 & 128 & 83 & 10 & 382 & 434 \\
\hline s.d. & & 0.43 & 1.22 & 0.94 & 6.92 & 18 & 5 & 4 & 97 & 50 \\
\hline
\end{tabular}


Table 6. Mineral composition of alder leaves, Alnus incana.

\begin{tabular}{|c|c|c|c|c|c|c|c|c|c|c|}
\hline $\begin{array}{l}\text { Fertili- } \\
\text { zation }\end{array}$ & & P & $\begin{array}{c}\mathrm{Ca} \\
\mathrm{g} / \mathrm{kg}\end{array}$ & $\stackrel{\mathrm{Mg}^{\mathrm{M}}}{ }$ & $\mathrm{K}$ & $\mathrm{Na}$ & $\mathrm{Fe}$ & $\begin{array}{c}\mathrm{Cu} \\
\mathrm{g} / \mathrm{kg} \mathrm{DM}\end{array}$ & $\mathrm{Zn}$ & Mn \\
\hline Control & & 1.06 & 1.37 & 3.82 & 2.67 & 66 & 80 & 7 & 61 & 530 \\
\hline Ash & & 1.28 & 13.69 & 1.87 & 8.39 & 67 & 99 & 8 & 65 & 495 \\
\hline NPK I & & 1.75 & 13.41 & 1.64 & 14.98 & 102 & 96 & 5 & 72 & 511 \\
\hline \multirow[t]{3}{*}{ NPK II } & & 1.68 & 12.41 & 1.65 & 14.33 & 79 & 88 & 8 & 67 & 528 \\
\hline & $\tilde{\mathbf{x}}$ & 1.44 & 13.47 & 2.25 & 10.09 & 78 & 91 & 7 & 66 & 516 \\
\hline & s.d. & 0.33 & 0.81 & 1.06 & 5.77 & 17 & 9 & 1 & 5 & 16 \\
\hline
\end{tabular}

The mineral composition varied somewhat within the clones. The fertilizer had a significant effect on the mineral composition of willow leaves. The calcium content decreased $2 \mathrm{~g}$ per $\mathrm{kg} \mathrm{DM}$ and the magnesium like wise to half of the control, but phosphorus increased $1 \mathrm{~g}$ per $\mathrm{kg} \mathrm{DM}$ and potassium over $10 \mathrm{~g}$ per $\mathrm{kg} \mathrm{DM}$ or twice to that of the control.

Nowadays leaves are of small importance as feed for domestic animals. For wild ruminants leaves are important as a feed source. Previously, leaves were collected in bundles for ruminants, mainly for sheep. Leaves are considered a suitable supplement to a ration predisposing to deficiencies in protein, minerals and vitamins and may accordingly serve as a protective feed. When feed resources were scarce, leaves were used as emergency feeds (POIJÄRVI 1940, NEHRING and SCHÜTTE 1951, BREIREM and HOMB 1970, MASSON andDECAEN 1980).

Energy forestry produces considerable amounts of green biomass of good nutritive value (SIREN et. al. 1970). This by-product from energy production should be made use of as a protein source for animals. Some tehcnical problems arise in the collecting and conservation of leaves. Besides the conventional drying, silage making and leaf protein production should be investigated.

\section{Conclusion}

As a by-product of biotic energy production using fast-growing energy crops, a green fodder yield corresponding to a moderate yield of normal pasture in Finnish conditions could be harvested. This fodder reserve must be considered on a national scale a considerable source of food for domestic animals or wild ruminants. The possible methods in harvesting and conservation of leaves would be silage making for ruminants or leaf protein extraction for non-ruminants using the pulp for ruminants as a roughage.

On the global scale energy farming cannot compete on land area with food crops. Therefore the suitable areas for the purpose have been sought outside the areal crop growing zones, for instance in northern peatland forests (POHJONEN 1980). The other possibility is a combined energy and green fodder production which opens new alternatives in the management of land area resources. 


\section{References}

BECKER, M. \& NEHRING, K. 1965. Laub- und Reisigfutterstoffe. Handbuch der Futtermittel II: 1-27. Hamburg und Berlin.

BREIREM, K. \& HOMB, T. 1970. Formidler og forkonservering 459 p. Gjфvik.

MASSON, B. \& DECAEN, C. 1980. Composition chemique et valeur alimentaire des jeunes pousses de peuplier (Populus) et de frene (Fraxinus). Ann. Zootech. 29: 195-200.

NEHRING, K. \& SCHÜTTE, J. 1951. Über die Zusammensetzung und den Futterwert von Laub und Reisig. Arch. Tierernähr. 1. 151-176.

PALOHEIMO, L. 1969. Weender Analyse. Handbuch der Tierernährung 1: 164-171. Hamburg.

POHJONEN, V. 1974. Effect of spacing on the first year yield and height increment of some species undergoing short rotation culture. Silva Fennica 8. 115-127.

- 1980. Energy willow farming on old peat industry areas. Paper presented at the 6 th International Peat Congress, Duluth USA, 1980.

- , KAUPPI, P., PELKONEN, P. \& SIREN, G. 1980. Biotic solar energy, Maniscript.

POIJÄRVI, I. 1940. Lehdeksistä ynnä eräistä muista apurehuista. Maatalous 33: 61-65.

SIREN, G., BLOMBÄCK, B. \& ALDEN, T. 1970. Proteins in forest tree leaves. Inst. för skogsföryngring. Rapp. och Uppsatser No 28, 22 p.

- \& SILVERTSON, E. 1976. Överlevelse och production hos snabbväxande Salix- och Populus-kloner för skogindustri och energiproduction. Pilotsstudie. Inst. för skogsföryngring.. Rapp. och Uppsatser. No. 83.

TAYSSKY, H.H. \& SHORR, E. 1953. A microcolorimetric method for determination of inorganic phosphorus. J. Biol. Chem. 202: 675-685.

TILLEY, J.M.A. \& TERRY, R.A. 1963. A two-stage technique for the in vitro determination of forage crops. J.Br. Grassland Soc. 18: 104-111.

Ms received June 8, 1981.

SELOSTUS

Energiametsän lehtimassa rehuna

Matti Näsi

Helsingin yliopisto, kotieläintieteen laitos, 00710 Helsinki 71

Veli Pohjonen

Metsäntutkimuslaitos, 69100 Kannus

Tutkimuksessa selvitettiin energiametsän lehtimassan satoa, kemiallista koostumusta ja in vitro sulavuutta pyrkimyksenä lyhytkiertopuiden kokonaiskäyttö. Lehtien osuus oli 31 \% vesipajulla (Salix cv. Aquatica) ja $16 \%$ koripajulla (S. viminalis) koko biomassan tuotannosta. Lehtien kuiva-ainetuotos oli 3-5 tn/ha. Pajunlehtien kemiallinen koostumus oli seuraava: kuiva-aine $27 \%$, tuhka $7.7 \%$, raakaproteiini $19.5 \%$, raakarasva $4.9 \%$ ja raakakuitu $14.1 \%$. Pajunlehtien tanniinipitoisuus oli $4.1 \%$ ja lepänlehtien $3.4 \%$. Lannoituksella oli vaikutusta pajunlehtien raakaproteiinin ja tuhkan pitoisuuksiin. Lepänlehtien kuitupitoisuus oli korkeampi kuin pajunlehdissä. Pajunlehtien orgaanisen aineen in vitro-sulavuus oli $64 \%$ ja pepsiini-HCl-liukoinen valkuainen 65 $\%$. Lannoitus paransi sulavuutta 6-8\%-yksikköä. Pajunlehdet sisālsivät kalsiumia $10 \mathrm{~g} / \mathrm{kg} \mathrm{ka}$, fosforia $3 \mathrm{~g} / \mathrm{kg} \mathrm{ka}$ ja magnesiumia $2.8 \mathrm{~g} / \mathrm{kg}$ ka. Hivenainepitoisuudet olivat myös korkeita. Korkean raakavalkuais- ja kivennäispitoisuuden takia energiametsän lehtimassa edustaa suhteellisen hyvāä rehulähdettä sekä kotielāimille että riistaeläimille. Lehtien korjuu ja säilöntä on teknisesti ratkaisematta. 